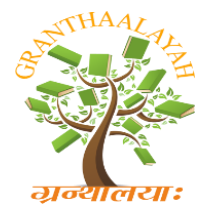

INTERNATIONAL JOURNAL OF RESEARCH -

GRANTHAALAYAH

A knowledge Repository

Management

\title{
RECENT SCENARIO OF CURRENT ACCOUNT DEFICIT IN INDIA
}

\author{
Ms. Yogambal $\mathbf{N}^{* 1}$ \\ ${ }^{* 1}$ Assistant Professor / MBA, PSV College of Engineering and Technology, INDIA
}

\begin{abstract}
Current Account Deficit topic deals with the meaning, the overview of the concept related with current scenario of the balance of trade. Through this paper we can come to know Gross Domestic position till recent date and impact of current account deficit. Just it gives idea whether current account deficit really harmful or good sign. This paper reveals the evaluation of current account deficit and also, reflection in various ways and also the implications of the reversals. It was concluded with few ideas which were shared as the suggestions to overcome the current account deficit. Global trends were analysed to know our country status.
\end{abstract}

Keywords:

current account, balance of payment, current account, Gross domestic product deficit, Intratemporal.

Cite This Article: Ms. Yogambal N, "RECENT SCENARIO OF CURRENT ACCOUNT DEFICIT IN INDIA" International Journal of Research - Granthaalayah, Vol. 4, No. 5: SE (2016): 106-112.

\section{INTRODUCTION}

A current account deficit means the value of imports of goods, services, and investment incomes is greater than the value of exports. It is sometimes referred to as a trade deficit the current account deficit is a broader measure that includes the trade deficit and is itself part of a broader measure, the balance of payments. The balance of payments is the sum of all transactions between a nation and all of its international trading partners. In addition to the trade deficit, the current account deficit includes factor income and financial transfers.

Factor income is determined by subtracting income made by citizens of a country on their foreign investments from income earned by foreigners on their investments within the country. An example of factor income is rental profit earned by citizens of one country on property they own in another country.

Financial transfers include interest earnings and foreign remittances. Foreign remittance refers to money earned in one country that is sent back to another country, as in the case of a person working outside his or her home country and sending money back home to relatives. In some 
cases, remittances constitute a significant portion of the gross domestic product (GDP) of the country where they are received. The current account is a calculation of a country's foreign transactions, and along with the capital account is a component of a country's balance of payment. If there is a current account deficit it means there is a surplus financial and capital account Balance of Trade in India is reported by the Ministry of Commerce and Industry India recorded a USD 7639 million trade deficit in January of 2016, lower than a USD 7872 million gap a year earlier and reaching the smallest shortfall since February of 2015. Exports fell 13.6 percent to USD 21,080 million, the 14th straight month of decline, as non-petroleum exports declined by 10.55 percent to USD 19,116 million. Imports dropped 11 percent year-on-year to USD 28,710 million, following a 3.88 percent fall in the previous month. While oil purchases slumped 39 percent, gold imports surged 85.2 percent. Balance of Trade in India averaged 2091.30 USD Million from 1957 until 2015, reaching an all-time high of 258.90 USD Million in March of 1977 and a record low of -20210.90 USD Million in October of 2012.

India has been recording sustained trade deficits since 1980 mainly due to the high growth of imports, particularly of crude oil, gold and silver. In recent years, the biggest trade deficits were recorded with China, Saudi Arab, Iraq, Switzerland and Kuwait. India records trade surpluses with US, Singapore, Germany, Netherlands and United Kingdom.

\section{WHETHER CURRENT ACCOUNT DEFICIT IS A PROBLEM OR NOT}

If a current account deficit is financed through borrowing it is said to be more unsustainable. This is because borrowing is unsustainable in the long term and countries will be burdened with high interest payments. Russia was unable to pay its foreign debt back in 1998. Other developing countries have experience similar repayment problems Brazil, African countries (3rd World debt) Countries with large interest payments have little left over to spend on investment.

A factor behind the Asian crisis of 1997 was that countries had run up large current account deficits by attracting capital flows (hot money) to finance the deficit. But, when confidence fell, these hot money flows dried up, leading to a rapid devaluation and crisis of confidence.

If you run a current account deficit, it means you need to run a surplus on the financial / capital account. This means foreigners have an increasing claim on your assets, which they could desire to be returned at any time. For example, if you run a current account deficit, it could be financed by foreign multinationals investing in your country or the purchase of assets. There is a risk that your best assets could be bought by foreigners, reducing long term income and lower confidence for investment.

A current account deficit may imply that you are relying on consumer spending, and are becoming uncompetitive. This leads to lower growth of the export sector. This is particularly a problem for countries in the Euro - who cannot devalue to restore competitiveness. It used very large current account deficits and was a factor behind the EU recession of 2008-13.

A Balance of payments deficit may cause a loss of confidence by foreign investors. Therefore, there is always a risk, that investors will remove their investments causing a big fall in the value of your currency (devaluation). This can lead to decline in living standards. 


\section{FEBRUARY 2016 STATUS}

India's current account deficit is likely to narrow to 0.7 per cent of GDP in the current financial year from 1.3 per cent in FY15, owing to lower commodity prices. The current account deficit, which occurs when the value of imports and investments is larger than value of exports, is expected to narrow to 0.4 per cent of GDP in the fourth quarter of 2015 from 1.6per cent of GDP in the previous quarter, the Japanese financial services major said. "For FY16, despite sluggish export volumes (weak global demand) and rising import volumes (stronger domestic demand and REER appreciation), we expect the current account deficit to narrow to 0.7 per cent of GDP from 1.3 per cent in FY15, owing to lower commodity (particularly oil) prices, The report noted that much of the weakness in both exports and imports is largely price-driven, owing to low commodity prices.

According to official figures, India's exports contracted 13.6 per cent in January - for the 14th month in a row - to $\$ 21$ billion. Imports too shrank 11 per cent to $\$ 28.71$ billion last month, leaving a trade deficit of $\$ 7.63$ billion as against $\$ 7.87$ billion in the same month last year. "External headwinds remain strong as seen in falling non-oil export volumes". "While import volumes have so far been steady, January data show signs of weakness," it had said. For the first 10 months of the current fiscal year, cumulative exports declined by 17.65 per cent to $\$ 217.67$ billion, as against $\$ 264.32$ billion in April-January period of 2014-15. Imports dipped by 15.46 per cent to $\$ 324.52$ billion for the 10 months, leaving a trade deficit of $\$ 106.8$ billion, data released by the Commerce Ministry showed. In the July-September quarter of the current fiscal year, current account deficit rose to $\$ 8.2$ billion or 1.6 per cent of GDP, from 1.2 per cent or $\$ 6.1$ billion in the April-June quarter.

\section{CURRENT ACCOUNT DEFICIT IS NOT NECESSARILY HARMFUL}

Current Account deficit could occur during a period of inward investment (surplus on financial account). This inward investment can create jobs and investment. E.g. US ran a current account deficit for a long time as it borrowed to invest in its economy. This enabled higher growth and so it was able to pay its debts back and countries had confidence in lending the US money. Japanese investment has been good for UK economy not only did the economy benefit from increased investment but the Japanese firms also helped bring new working practices in which increased labour productivity.

1) With a floating exchange rate a large current account deficit should cause a devaluation which will help automatically reduce the level of the deficit.

2) A current account deficit may just indicate a strong economy, which is growing rapidly.

\section{EVALUATION}

It depends on the size of the current account deficit as a \% of GDP. For example, a deficit of over $5 \%$ would be cause for greater concern.

- It depends on how you are financing the current account deficit. If a country is borrowing from abroad to finance consumption, this is damaging in the long-term. If it is financing the 
current account deficit through attracting long-term capital investment, this could have positive benefits. It depends on the country in question; the US probably has less reason to be concerned about a current account deficit. The US can attract a lot of capital flows to buy dollar securities. However, a developing economy may be more vulnerable to a current account deficit. This is because investors may be quicker to fear an economic downturn and remove their capital. The current account deficit seems to be an abstruse economic concept. But in countries that are spending a lot more abroad than they are taking in, the current account is the point at which international economics collides with political reality. When countries run large deficits, businesses, trade unions, and parliamentarians are often quick to point accusing fingers at trading partners and make charges about unfair practices. Tension between the United States and China about which country is primarily responsible for the trade imbalance between the two has thrown the spotlight on the broader consequences for the international financial system when some countries run large and persistent current account deficits and others accumulate big surpluses.

\section{MEASURING CURRENT ACCOUNT}

- There are several points at issue - including what a current account deficit or surplus really means and the many ways that current accounts balance is measured.

- The current account can be expressed as the difference between the value of exports of goods and services and the value of imports of goods and services. A deficit then means that the country is importing more goods and services than it is exporting-although the current account also includes net income (such as interest and dividends) and transfers from abroad (such as foreign aid), which are usually a small fraction of the total. Expressed this way, a current account deficit often raises the hackles of protectionists, who apparently forgetting that a main reason to export is to be able to import - think that exports are "good" and imports are "bad."

- The current account can also be expressed as the difference between national savings and investment.

\section{REFLECTION OF CURRENT ACCOUNT DEFICIT}

A current account deficit may therefore reflect a low level of national savings relative to investment or a high rate of investment - or both. For capital-poor developing countries, which have more investment opportunities than they can afford to undertake because of low levels of domestic savings, a current account deficit may be natural. A deficit potentially spurs faster output growth and economic development - although recent research does not indicate that developing countries that run current account deficits grow faster (perhaps because their less developed domestic financial systems cannot allocate foreign capital efficiently). Moreover, in practice, private capital often flows from developing to advanced economies. The advanced economies, such as the United States run current account deficits, whereas developing countries and emerging market economies often run surpluses or near surpluses. Very poor countries typically run large current account deficits, in proportion to their gross domestic product (GDP), that are financed by official grants and loans. 


\section{WAYS TO IMPROVE CURRENT ACCOUNT BALANCE}

One point that the savings-investment balance approach underscores is that protectionist policies are unlikely to be of much use in improving the current account balance because there is no obvious connection between protectionism and savings or investment.

Another way to look at the current account is in terms of the timing of trade. We are used to intratemporal trade-exchanging cloth for wine today. But we can also think of intertemporal trade - importing goods today (running a current account deficit) and, in return, exporting goods in the future (running a current account surplus then). Just as a country may import one good and export another under intratemporal trade, there is no reason why a country should not import goods of today and export goods of tomorrow.

Intertemporal theories of the current account also stress the consumption-smoothing role that current account deficits and surpluses can play. For instance, if a country is struck by a shockperhaps a natural disaster - that temporarily depresses its ability to access productive capacity, rather than take the full brunt of the shock immediately, the country can spread out the pain over time by running a current account deficit. Conversely, countries that are subject to large shocks should, on average, run current account surpluses as a form of precautionary saving.

It matter the duration of current account deficit. When a country runs a current account deficit, it is building up liabilities to the rest of the world that are financed by flows in the financial account. Eventually, these need to be paid back. Common sense suggests that if a country fritters away its borrowed foreign funds on spending that yields no long-term productive gains, then its ability to repay its basic solvency might come into question. This is because solvency requires that the country be willing and able to generate (eventually) sufficient current account surpluses to repay what it has borrowed to finance the current account deficits. Therefore, whether a country should run a current account deficit (borrow more) depends on the extent of its foreign liabilities (its external debt) and on whether the borrowing will finance investment with a higher marginal product than the interest rate (or rate of return) the country has to pay on its foreign liabilities.

But even if the country is intertemporally solvent-meaning that current liabilities will be covered by future revenues - its current account deficit may become unsustainable if it is unable to secure the necessary financing. While some countries (such as Australia and New Zealand) have been able to maintain current account deficits averaging about $41 / 2$ to 5 percent of GDP for several decades, others (such as Mexico in 1995, Thailand in 1997, and several economies during the recent global crisis) experienced sharp reversals of their current account deficits after private financing withdrew during the financial crisis.

Such reversals can be highly disruptive because private consumption, investment, and government expenditure must be curtailed abruptly when foreign financing is no longer available and, indeed, a country is forced to run large surpluses to repay in short order what it borrowed in the past. This suggests that-regardless of why a country has a current account deficit (and even if the deficit reflects desirable underlying trends) - large and persistent deficits call for caution, lest a country experience an abrupt and painful reversal of financing. 


\section{IMPLICATION OF THE REVERSAL}

If a country experiences such a reversal it implies that an overvalued real exchange rate, inadequate foreign exchange reserves, excessively fast domestic credit growth, unfavorable terms of trade shocks, low growth in partner countries, and higher interest rates in industrial countries influence the occurrence of reversals. More recent literature has also focused on the importance of balance sheet vulnerabilities in the run-up to a crisis - such as the extent to which companies have large liabilities in foreign currencies such as dollars or maturity mismatches that occur when companies have more short-term liabilities than short-term assets and more mediumand long-term assets relative to their liabilities. Recent research has also underscored the importance of the composition of capital inflows the relative stability of foreign direct investment compared with more volatile short-term investment flows, such as in equities and bonds. Moreover, weak financial sectors can often increase a country's vulnerability to a reversal of investment flows as banks borrow money from abroad and make risky domestic loans. Conversely, a more flexible policy framework-such as a flexible exchange rate regime, a higher degree of openness, export diversification, and coherent fiscal and monetary policies-combined with financial sector development could help a country with persistent deficits be less vulnerable to a reversal by allowing greater room for better shock absorption.

\section{CONCLUSION}

A common complaint about economics is that the answer to any question is, "It all depends." It is true that economic theory tells us that whether a deficit is good or bad depends on the factors giving rise to that deficit, but economic theory also tells us what to look for in assessing the desirability of a deficit.

If the deficit reflects an excess of imports over exports, it may be indicative of competitiveness problems, but because the current account deficit also implies an excess of investment over savings, it could equally be pointing to a highly productive, growing economy. If the deficit reflects low savings rather than high investment, it could be caused by reckless fiscal policy or a consumption binge or it could reflect perfectly sensible intertemporal trade, perhaps because of a temporary shock or shifting demographics. Without knowing which of these is at play, it makes little sense to talk of a deficit being "good" or "bad." Deficits reflect underlying economic trends, which may be desirable or undesirable for a country at a particular point in time.

\section{REFERENCES}

[1] Regi, S. B., \& Golden, S. A. R. (2014). Foreign Direct Investment- An Overview. IJARCSMS, 2(2).

[2] Regi, S. B., \& Golden, S. A. R. (2014). Reforms In Insurance Sector In India- A Empirical Study. Review of Research, 3(9), 1-5.

[3] Regi, S. B., \& Golden, S. A. R. (2014). Global Financial Crisis - Impact In India. JOURNAL OF INTERNATIONAL ACADEMIC RESEARCH FOR MULTIDISCIPLINARY, 2(1), JIARM.

[4] http://profit.ndtv.com/news/budget/article-current-account-deficit-to-narrow-to-0-7-ofgdp-nomura-1278527 
[5] http://profit.ndtv.com/news/budget/article-current-account-deficit-to-narrow-to-0-7-ofgdp-nomura-1278527

[6] http://economictimes.indiatimes.com/topic/current-account-deficit

[7] https://en.wikipedia.org/wiki/Current_account

[8] http://www.economicshelp.org/macroeconomics/bop/probs-balance-payments-deficit/

[9] http://www.economicshelp.org/macroeconomics/bop/probs-balance-payments-deficit/

[10] http://www.imf.org/external/pubs/ft/fandd/basics/current.htm 